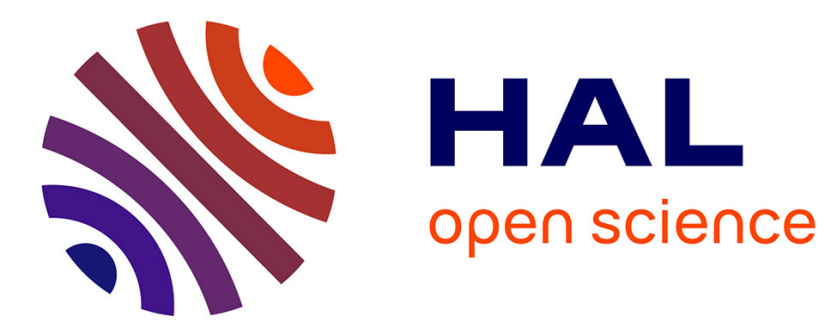

\title{
Cell intrinsic and extrinsic mechanisms of stem cell aging depend on telomere status
}

\author{
Zhangfa Song, Zhenyu Ju, K. Lenhard Rudolph
}

\section{To cite this version:}

Zhangfa Song, Zhenyu Ju, K. Lenhard Rudolph. Cell intrinsic and extrinsic mechanisms of stem cell aging depend on telomere status. Experimental Gerontology, 2008, 44 (1-2), pp.75. 10.1016/j.exger.2008.06.009 . hal-00499060

\section{HAL Id: hal-00499060 https://hal.science/hal-00499060}

Submitted on 9 Jul 2010

HAL is a multi-disciplinary open access archive for the deposit and dissemination of scientific research documents, whether they are published or not. The documents may come from teaching and research institutions in France or abroad, or from public or private research centers.
L'archive ouverte pluridisciplinaire HAL, est destinée au dépôt et à la diffusion de documents scientifiques de niveau recherche, publiés ou non, émanant des établissements d'enseignement et de recherche français ou étrangers, des laboratoires publics ou privés. 


\section{Accepted Manuscript}

Cell intrinsic and extrinsic mechanisms of stem cell aging depend on telomere status

Zhangfa Song, Zhenyu Ju, K. Lenhard Rudolph

PII:

S0531-5565(08)00173-3

DOI:

10.1016/j.exger.2008.06.009

Reference:

EXG 8510

To appear in:

Experimental Gerontology

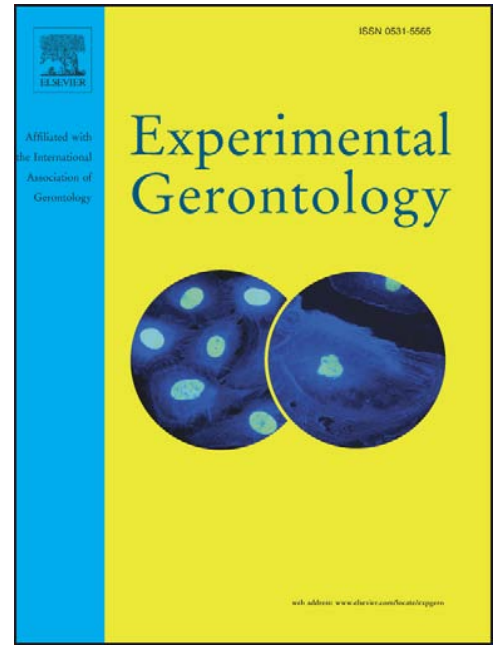

Received Date: $\quad 12$ June 2008

Revised Date: $\quad 24$ June 2008

Accepted Date: $\quad 25$ June 2008

Please cite this article as: Song, Z., Ju, Z., Rudolph, K.L., Cell intrinsic and extrinsic mechanisms of stem cell aging depend on telomere status, Experimental Gerontology (2008), doi: 10.1016/j.exger.2008.06.009

This is a PDF file of an unedited manuscript that has been accepted for publication. As a service to our customers we are providing this early version of the manuscript. The manuscript will undergo copyediting, typesetting, and review of the resulting proof before it is published in its final form. Please note that during the production process errors may be discovered which could affect the content, and all legal disclaimers that apply to the journal pertain. 
Cell intrinsic and extrinsic mechanisms of stem cell aging depend on telomere status

$$
\text { Zhangfa Song }{ }^{1} \text {, Zhenyu Ju }{ }^{1,2} \text {, K. Lenhard Rudolph }{ }^{1}
$$

1.Institute of Molecular Medicine and Max-Planck-Research Group on Stem Cell Aging, University of Ulm, 89081, Germany;

2.Institute of Laboratory Animal Sciences and Max-Planck-Partner Group on Stem Cell Aging, Chinese Academy of Medical Sciences, China.

Address for correspondence:

K- Lenhard Rudolph

Institute of Molecular Medicine and

Max-Planck-Research Group on Stem Cell Aging

University of Ulm

89081 Ulm

Germany

Email: Lenhard.Rudolph@uni-ulm.de

Tel./Fax: 0049-731-5036-100/-102

Zhenyu Ju

Institute of Laboratory Animal Sciences and Max-Planck-Partner Group on Stem Cell Aging,

Chinese Academy of Medical Sciences

China

Email: zhenyuju@hotmail.com

Tel./Fax: 0086-10-6777-6051/6838 
The function of adult stem cells declines during aging and chronic diseases. An understanding of the molecular mechanisms underlying these processes will help to identify targets for future therapies in order to improve regenerative reserve and organ maintenance. Telomere shortening represents a cell intrinsic mechanism inducing DNA damage in aging cells. Current studies in telomerase knockout mice have shown that telomere dysfunction induces cell intrinsic checkpoints and environmental alteration that limit stem cell function. While these phenotypes differ from wildtype mice with long telomere reserves, they appear to be relevant for human aging, which is associated with an accumulation of telomere dysfunction and DNA damage.

\section{Introduction}

There is growing evidence for a functional decline of adult stem cells during aging. In aging mammals, the functional reserve of adult stem cells decreases in the hematopoietic system (Waterstrat et al., 2008.), in pancreatic islets (Krishnamurthy et al., 2006), in areas of neurogenesis in the brain (Molofsky et al., 2006), in hair follicles (Nishimura et al., 2005), in intestinal crypts (Martin et al., 1998), and in muscle (Brack and Rando, 2007).

Several lines of evidence indicate that the decline in stem cell function during aging can involve both cell intrinsic mechanisms and environmental alterations [for review see: (Ju and Rudolph, 2008)]. In humans, it has been shown that both donor age (Castro-Malaspina et al., 2002; Kollman et al., 2001) and recipient age (Kantarjian et al., 2006; Socie et al., 1999) influence patients' outcomes in response to hematopoietic stem cell (HSC) transplantation. These clinical data indicate that cell intrinsic and cell extrinsic (environmental) mechanisms could contribute to the functional decline of HSCs during human aging. The relative contribution of these mechanisms to the decline in function and maintenance of aging stem cells remains to be defined in different organ systems and genetic modifiers have yet to be identified. Overcoming these obstacles may provide a rational basis to begin therapeutic strategy development, which could improve regenerative reserve during aging. In this review, we focus on the influence of telomere dysfunction on cell intrinsic and cell extrinsic mechanisms limiting stem cell function during aging.

\section{Telomere shortening and cellular aging}

Telomeres consist of simple tandem DNA repeats and associated telomere binding proteins (de Lange, 2005). The main function of telomeres is to cap chromosome ends thus preventing an activation of DNA damage responses and the evolution of chromosomal instability (Blackburn, 2001). Telomeres shorten with each round of cell division due to the 'end replication problem' of DNA polymerase and due to processing of telomeres during cell cycle (Levy et al., 1992; Sfeir et al., 2005). The enzyme telomerase is required to compensate for telomere shortening. Telomerase synthesizes telomeres de novo. In humans, telomerase is active during embryogenesis (Wright et al., 1996), but it is suppressed in most somatic cells after birth. In adults, telomerase remains active in germ cells and certain stem cell compartments, like in intestinal stem cells and 
hematopoietic stem cells (Broccoli et al., 1995, for review see: Zimmermann and Martens, 2005, Artandi, 2008) . In addition, telomerase is transiently up-regulated in stimulated lymphocytes (Hiyama et al., 1995).

Telomere shortening limits the lifespan of primary human cells to a finite number of cell divisions, which is 50-70 for human fibroblast. This limit is called after the discoverer - the 'Hayflick limit' (Hayflick, 1965). Studies on over-expression of telomerase have proven that telomere shortening is the underlying mechanism limiting the lifespan of human cells (Bodnar et al., 1998). Since most primary human cells lack telomerase expression the lifespan of human cells is limited by telomere shortening. Studies on human fibroblasts have shown that telomere shortening induces two checkpoints. The first checkpoint is activated in response to low levels of telomere dysfunction [3-5 dysfunctional telomeres per cell, (Zou et al., 2004)]. At this stage human fibroblasts enter a permanent cell cycle arrest, which is called replicative senescence (Wright and Shay, 1992). Human fibroblasts can escape the senescence checkpoint when p53 and Rb checkpoints are abrogated (Wright and Shay, 1992). However, during this extended lifespan period (ca. 10-20 cell divisions) telomeres continue to shorten and eventually reach a second checkpoint, which is called crisis (Wright and Shay, 1992). Crisis is characterized by high levels of telomere dysfunction, massive chromosomal instability, and cell death.

\section{Telomere shortening and human aging}

There is ample evidence that telomeres shorten during human aging (Jiang et al., 2007). This shortening also affects stem cell compartments, e.g., telomeres shorten in CD34+ hematopoietic cells during human aging (Vaziri et al., 1994), although human HSCs exhibit low level of telomerase activity. Together, it appears that telomerase expression contributes to the proliferative capacity of human HSCs but the level of telomerase expression is not sufficient to maintain stable telomeres into old age (Zimmermann and Martens, 2005).

In addition to telomere shortening during aging, various chronic diseases accelerate telomere shortening in humans (Jiang et al., 2007). This has been reported for different forms of anemia, hypertension, coronary heart diseases, chronic HIV infection, ulcerative colitis, chronic liver disease, and others (Wiemann et al., 2002, Jiang et al. 2007). Moreover, telomere shortening during chronic diseases is often associated with disease progression (Jiang et al. 2007, Wiemann et al., 2002). It has also been documented that telomere shortening correlates with age-related pathology and reduced human lifespan (Cawthon et al., 2003; Collerton et al., 2007). Lastly, mutations in human telomerase genes lead to telomere shortening, stem cell defects, impaired organ maintenance and a shortened lifespan (Armanios et al., 2007; Tsakiri et al., 2007; Vulliamy et al., 2004). Together, these data strongly indicate that human telomere reserves are limited. New experimental data indicate that increasing levels of biomarkers of telomere dysfunction and DNA damage characterize human aging and aging-associated disease (Jiang et al. 2008). Given the pivotal role of telomeres and adult stem cells for tissues maintenance and repair, it appears to be of utmost importance to understand the functional consequences of telomere dysfunction on stem cell levels. The characterization of stem cell aging in wild type mice cannot address this critical question since laboratory wild type mouse strains have very long telomeres compared to humans 
(Prowse and Greider, 1995) and inbred laboratory wildtype mice do not experience significant levels of telomere dysfunction during aging (Jiang et al. 2008). In fact, there is experimental evidence that the decline in stem cell function in wild type laboratory mouse strains is mainly driven by telomere-independent mechanisms (Allsopp et al., 2003).

\section{DNA damage signalling in response to telomere dysfunction}

Critical telomere shortening leads to uncapping of chromosomal ends. These dysfunctional telomeric ends are recognized as DNA double strand breaks, that lead to activation of DNA-damage checkpoints (d'Adda di Fagagna et al., 2003; Takai et al., 2003). DNA damage signals in response to telomere dysfunction are similar to those induced by $\gamma$-irradiation. The initial step of this DNA damage signalling is the formation of DNA damage foci at dysfunctional telomeres. These foci consist of proteins involved in DNA damage recognition and repair including $\gamma \mathrm{H} 2 \mathrm{AX}$, 53bp1, NBS1, MDC1, among others (d'Adda di Fagagna et al., 2003; Satyanarayana et al., 2004). These DNA damage foci induce ATM/Chk2 and ATR/Chk1 kinase pathways (d'Adda di Fagagna et al., 2003) activating p53 (Gire et al., 2004, Chin et al., 1999) and its downstream target p21 (Brown et al., 1997)inducing cellular senescence (Brown et al., 1997). In contrast to the senescence checkpoint, the crisis checkpoint is less well understood and may involve an activation of multiple p53-independent checkpoints inducing cell death.

There is a continuous need to investigate checkpoints in response to telomere dysfunction using in vivo models. It is conceivable that telomere dysfunction induces different checkpoint responses depending on the tissue type. In addition, checkpoint responses in stem cells may differ from somatic cells. In line with this assumption, it has been shown that embryonic stem cells lack efficient G1 cell cycle checkpoints in response to $\gamma$-irradiation (Hong and Stambrook, 2004). It is currently unknown whether similar differences are present in adult stem cells compared to somatic cells. Given the difficulties in culturing undifferentiated, adult stem cells, it is necessary to investigate consequences of telomere dysfunction using in vivo models.

\section{Telomere shortening and stem cell aging}

Inbred laboratory mice have long telomeres ( $25-60 \mathrm{~kb}$ compared to $10-12 \mathrm{~kb}$ in humans) and a short lifespan (24-30 months) compared to 75-80 years in humans (Cawthon et al., 2003; Choudhury et al., 2007; Prowse and Greider, 1995). Using an unbiased proteomic approach we have recently identified biomarkers of telomere dysfunction. These markers show an increased expression in various tissues and blood plasma of aging telomere dysfunctional mice but not in wildtype controls. The same biomarkers significantly increase during human aging and aging-associated disease (Jiang et al. 2008). Together these results support the hypothesis that accumulation of telomere dysfunction and DNA damage contribute to human aging, but have little impact on aging of wild type mice with long telomere reserves. Thus, telomerase knockout mice provide a unique experimental model to study the in vivo consequences of this important aspect of human aging. 
Current experimental evidence indicates that telomere shortening influences stem cell aging. In some wild type mouse strains (e.g., C57B1/6J) the number of HSCs increases during aging, whereas other mouse strains, such as DAB2 and BalbC, show a decrease in HSC number during aging (Morrison et al., 1996, Waterstrat et al., 2008.). Interestingly, the number of HSCs has been associated with murine lifespan (Henckaerts et al., 2004; Van Zant et al., 1990).

Although HSCs in wildtype C57B1/6J mice acquire defects in long-term repopulating potential during aging, the total stem cell activity remains fairly constant due to the increase in stem cell number in this strain (Chambers et al., 2007). Moreover, C57BL/6J mice rarely develop hematopoietic failure during aging. This scenario appears to be very different from human aging, which is characterized by a decline in HSC number (Waterstrat et al.,2008), and frequent occurrence of bone marrow failure and anemia (Beghe et al., 2004). It appears likely that shorter telomeres and longer lifespan in humans represent fundamental differences affecting stem cell aging in humans but not in C57BL/6J mice. In agreement with this assumption, heterozygous mutations in telomerase gene impair telomerase activity by haplo-insufficiency and represent risk factors for bone marrow failure in human aplastic anemia and dyskeratosis congenita (DC) (Vulliyami et al., 2004). In contrast, heterozygous mutations of telomerase in C57BL/6J mice with long telomeres have little effect on stem cell function during aging (Choudhury et al., 2007). However, the heterozygous deletion of telomerase in a mouse strain with short telomeres (CAST/EjI) induced stem cell defects and impairment of organ maintenance similar to the human situation (Hao et al., 2005). Together, these results indicate that laboratory mouse strains with long telomeres lack telomere shortening, which represent one important aspect of human aging.

Studies on telomerase knockout mice (Terc-/-) have provided first experimental evidence that telomere shorting has a causal role in limiting organ maintenance and lifespan (Rudolph et al., 1999). Terc-/- mice with short telomeres showed premature aging phenotypes, specifically affecting organ systems with high rate of cell turnover (Choudhury et al., 2007; Ju et al., 2007; Lee et al., 1998). Aging phenotypes of hematopoietic stem cells in Terc-/- mice are different from HSC aging in wild type mice (Table 1). Given the prevalence of telomere shortening in human aging (see above) studies on Terc-/- mice may allow a better understanding of telomere dependent mechanisms of stem cell aging in humans.

In contrast to wild type C57BL/6J mice (see above), the number of long-term HSCs does not significantly expand in aging Terc-/- C57BL/6J mice with dysfunctional telomeres, but rather shows a decrease compared to age-matched wildtype controls (Choudhury et al., 2007). Moreover, Terc-/- mice more frequently develop hematopoietic failure, which also occurs during human aging, namely anemia and a reduction in lymphocytes and total white blood counts (Rudolph et al., 1999). In addition, telomere dysfunction impaired the function of HSCs in transplantation experiments (see below). In addition to the defects in the hematopoietic system, telomere dysfunctional mice exhibited a stem cell depletion phenotype affecting germ cells, intestinal stem cells, and neuronal stem cells (Choudhury et al., 2007; Ju et al., 2007; Wong et al., 2003). Together, these findings suggest that adult stem cells are the most sensitive cell compartment affected by telomere dysfunction.

In human, two important pathophysiological features of the aged hematopoietic system are a 
decrease in lymphopoiesis and immune function and an increase in myeloproliferative disease. Evidence from humans HSC transplantation (see above) and mice experiments (see below) indicate that stem cell intrinsic and extrinsic mechanisms contribute to the age-dependent decline in stem cell function.

In wild type mice, a similar skewing of hematopoiesis (decreased lymphoiesis, increased myelopoiesis) occurs during aging. This phenotype in wild type mice is transplantable and is characterised by cell intrinsic changes in gene expression suggesting that this phenotype can be induced by cell intrinsic mechanisms (Chambers et al., 2007; Rossi et al., 2005). However, there is also evidence that cell extrinsic alteration may contribute to impaired b-lymphopoiesis in aging wild type mice (Labrie et al., 2004; Stephan et al., 1998). Moreover, it was shown that the aging environment impairs the homing of transplanted HSCs (Liang et al., 2005).

In aging telomere dysfunctional Terc-/- C57BL/6J mice, the skewing of hematopoiesis is accelerated compared to wild type mice (Ju et al., 2007). Interestingly, the skewing of hemato-lymphopoiesis in Terc-/- mice is mainly induced by cell extrinsic alterations, whereas stem cell intrinsic checkpoints affect self-renewal and repopulation capacity of telomere dysfunctional HSCs (Ju et al., 2007, Choudhury et al., 2007).

Given the evidence for a functional role of telomere dysfunction during human aging (see above) the following section will provide a summary of cell intrinsic and extrinsic alterations that limit stem cell function in response to telomere dysfunction.

\subsection{Cell intrinsic checkpoints limiting stem cell function in response to telomere dysfunction}

Experiments in late generation mTerc-/- mice revealed first experimental evidence that cell intrinsic checkpoints contribute to the decline in stem cell function in response to telomere dysfunction and aging. Comparing studies on wild type and telomerase knockout mice it becomes clear that DNA damage checkpoint genes can have protective or detrimental effects on stem cell function depending on telomere status (Table 2).

(i) Exonuclease-1 (Exo1): Exo1 is a 5-3 prime exonuclease involved in the DNA mismatch repair pathway (Amin et al., 2001). Exol deletion rescued the induction of senescence in response to telomere dysfunction in yeast cells (Bertuch and Lundblad, 2004; Hackett and Greider, 2003; Maringele and Lydall, 2004) . In Terc-/- mice, Exo1 deletion improved the maintenance of intestinal stem cells and rescued the skewing of hemato-/lymphopoiesis in aging telomere dysfunctional mice. The study revealed that Exo1 deletion prevented the formation of single stranded DNA and the activation of ATR-p53-p21 signaling pathway (Schaetzlein et al., 2007). This rescue in DNA damage signaling was associated with improved cell cycle activity and reduced induction of apoptosis in intestinal stem and progenitor cells in response to telomere dysfunction. Studies on PMS2 have also shown a role of mismatch repair in DNA damage signaling in response to telomere dysfunction (Siegl-Cachedenier et al., 2007). In contrast to the rescue of intestinal stem cells in response to deletion of mismatch repair genes in telomere dysfunctional mice, the deletion of the mismatch repair gene MSH2 diminished the function of HSCs in wild tpe mice (Reese et al., 2003).

(ii) Ataxia Telangiectasia Mutated (ATM): Deletion of ATM did not rescue the activation of 
p53-signalling in telomere dysfunctional mice indicating that ATM-independent pathways can activate p53 in response to telomere dysfunction (Wong et al., 2003). Paradoxically the deletion of ATM enhanced aging phenotypes in mTERC $^{-/}$mice (Wong et al., 2003). A potential explanation is that ATM itself has a role in telomere capping and ATM deletion may increase telomere dysfunction (Bi et al., 2004).

In addition, ATM plays a crucial role in reactive oxygen species (ROS) metabolism and the increase in ROS level in ATM-/- cells may cooperate with telomere dysfunction to aggravate aging phenotypes. Indeed, ATM deficiency affected the function of HSCs in wild type mice with long telomeres (Ito et al., 2004). However, these defects only occurred in response to stress and not under homeostatic conditions in aging mice. Moreover, the effects of ATM mutations in humans (e.g. impaired organ homeostasis including neurodegeneration, immunodeficiency, and predisposition to malignancy) were not fully reproduced in $\mathrm{mTerc}^{+/+}$ mice with long telomere but to a greater extent in telomere dysfunctional mice (Wong et al., 2003). These data suggest that telomere shortening can cooperate with other genetic lesions to induce aging related pathology. In line with this assumption, Wrn knockout mice with long telomere reserves did not display typical cellular or clinical phenotypes of human Werner syndrome (Lombard et al., 2000). However, in late generation $\mathrm{Terc}^{-/}$mice, deletion of Wrn accelerated the overall attrition of telomere length, resulting in phenotypes resembling human Werner syndrome, including early onset of age-related disorders, increased incidence of mesenchymal cancers, and premature death (Chang et al., 2004; Du et al., 2004).

(iii) p53: p53 appears to have a more complicated role in stem cell aging. First, in Terc $^{+/+}$mice, $p 53$ seems to have a dose effect on organismal aging and stem cell function. Mice with a hypermorphic form of $p 53$ showed reduced longevity, osteoporosis, generalized organ atrophy, and impaired stress tolerance (Tyner et al., 2002). Moreover, overactive $p 53$ decreased the number and function of HSCs, whereas heterozygous deletion of $p 53$ increased proliferation of HSCs during mouse aging (Dumble et al., 2007). In contrast, mice containing an extra copy of naturally regulated $p 53$ and p19ARF(under control of the natural promoters of these genes) did not show increased tissue atrophy but an elongated lifespan (Matheu et al., 2007). The authors proposed that naturally regulated p53 is preferentially activated in damaged cells thus protecting the organisms from an accumulation of damaged cells. However, introducing an extra copy of p53 did not improve the lifespan of Terc-/- mice, although the load of damaged cells is higher in the context of telomere dysfunction in Terc-/- mice compared to wild type mice (Garcia-Cao et al., 2006). A possible explanation for this difference could be that an extra copy of p53 can only delay aging in a context of relatively mild accumulation of DNA and telomeric damage. In contrast, in the context of high levels of DNA or telomeric damage beneficial effects of higher checkpoint control may be counteracted by the fact that the number of surviving cells falls under a critical threshold. The consequences of increased activity of naturally regulated p53 on human aging remain speculative. The above discussed similarities between human aging and aging of telomere dysfunctional mice suggest that increased activity of p53 may not improve organismal fitness.

(iv) p21: Deletion of p21 improved organ homeostasis and elongated lifespan of telomere dysfunctional mice without accelerating cancer formation (Choudhury et al., 2007). A possible explanation is that apoptosis checkpoints remained intact preventing an increase in chromosomal instability and cancer formation. Interestingly, deletion of p21 improved self 
renewal and repopulation capacity of HSCs in aging telomere dysfunctional mice (Choudhury et al., 2007), but impaired stem cell maintenance and repopulation capacity of HSCs in wildtype mice (Cheng et al., 2000). However, the latter effect appears to show mouse strain specificity and may only be relevant in the context of replication stress (van Os et al., 2007). Together, p21 could have a dual role in aging stem cells (Ju et al., 2007). In non-damaged stem cells of wildtype mice, p21 contributes to the maintenance of stem cell quiescence thus preventing abnormal cycling and stem cell depletion. In contrast, p21 impairs self renewal and function of stem cells accumulating telomere dysfunction.

(v) p16/p19: Experiments in wild type mice showed that p16-deletion improved regenerative capacity in different stem cell compartments including HSCs, neuronal stem cells, and pancreatic islets. These data indicate that p16 might be one of the causal factors limiting stem cell function in aging wild type mice with long telomere reserves (Janzen et al., 2006; Krishnamurthy et al., 2006; Molofsky et al., 2006). In line with this hypothesis, expression of Bmi-1 (a repressor of p16) promotes stem cell self-renewal in wildtype mice (Hosen et al., 2007). In contrast to aging of wild type mice, p16 and p19ARF deletion did not improve organ maintenance and lifespan of telomere dysfunctional mice indicating that this pathway is not a major component limiting stem cell function in response to telomere dysfunction (Khoo et al., 2007).

Together the above studies show that cell intrinsic DNA damage checkpoints have very different effects on stem cell aging depending on the telomere status.

5.2 Cell extrinsic checkpoints limiting stem cell function in response to telomere dysfunction

Cell extrinsic mechanisms contribute to the decline in stem cell function in aging mice (Liang et al. 2005, Stephan et al. 1998, Labrie et al. 2004). Telomere dysfunction increased the influence of environmental alterations limiting the function of HSCs in aging mice. Experimental evidence for an accumulation of telomere dysfunction in aging humans (Jiang et al. 2008) and clinical data (Table 1) support the hypothesis that environmental alterations induced by telomere dysfunction could contribute to the decline in stem cell function in human aging.

One hallmarks of HSC aging is the skewing of hemato-/lymphopoiesis (decreased lymphopoiesis and increased myelopoiesis) occurring during human and mouse aging (Kim et al., 2003; Morrison et al., 1996; Rossi et al., 2005; Sudo et al., 2000). The skewing of hemato-/lymphopoiesis occurs in aging wild type mice and in Terc-/- mice with dysfunctional telomeres (Rossi et al., 2005; Rudolph et al., 1999; Ju et al., 2007). However, in Terc-/- mice, the phenotype is accelerated and appears earlier in life compared to wild type mice (Ju et al. 2007). Experimental data suggest that skewing of hemato-lymphopoiesis in aging wild type mice is induced by both cell-intrinsic and cell extrinsic mechanisms (see above and Labrie et al., 2004; Rossi et al., 2005; Stephan et al., 1998). In contrast, the skewing of hemato-/lymphopoiesis in aging mTerc-/- mice with dysfunctional telomeres was mainly due to cell extrinsic mechanisms. Skewing of hemato-lymphopoiesis was rescued when Terc-/- HSCs were transplanted into a 
wildtype environment. Moreover, young wildtype HSC showed skewing when transplanted into telomere dysfunctional recipients (Ju et al., 2007). Together, these results indicate that telomere dysfunction increases the influence of cell extrinsic factors on stem cell aging (Table 1).

The defects of the stem cell environment in telomere dysfunctional mice were age-dependent and correlated with progressive telomere shortening in bone marrow stromal cells (Ju et al. 2007). Telomere dysfunctional mice showed an impaired capacity of bone marrow stromal cells to maintain functional HSCs, and an increased expression of various cytokines, including granulocyte colony-stimulating factor (G-CSF) in blood serum and in supernatant of primary bone marrow stromal cells. Administration of G-CSF to wild-type mice mimicked some of the defects seen in aging telomere dysfunction mice, including impairment of b-lymphopoiesis and HSC engraftment. Conversely, inhibition of G-CSF improved HSC engraftment in aged telomere dysfunction mice.

Proteomic analysis on cell extrinsic proteins in culture supernatant of bone marrow from telomere dysfunctional mice has identified a new set of biomarker showing increased expression in response to telomere dysfunction in aging mTerc-/- mice (Jiang et al. 2008). Interestingly, these biomarkers showed increased expression in human cells in response to telomere dysfunction and irradiation induced DAN damage. Moreover, the expression levels of these proteins in blood serum were robust indicators for human aging and age related diseases indicating that similar cell extrinsic alterations occur in aging humans and telomere dysfunctional mice.

There is accumulating evidence that cell extrinsic alterations contribute to the decline in stem cell function in various organ systems during aging (Conboy et al., 2005; Ryu et al., 2006, Mackall and Gress, 1997; Kempermann et al., 2002, Collins et al.,2007 ). Emerging data suggest that systemically acting factors and alterations in cell-to-cell contact in stem niches impinge on stem cell aging (Boyle et al., 2007; Pan et al., 2007; Zhao et al., 2008) . The relative contribution of telomere dysfunction to these mechanisms of stem cell aging remains yet to be defined across different organ systems.

\section{Outlook}

In summary, current data suggest that self-renewing stem cells age because of cell intrinsic events and environmental alterations. Several lines of evidence suggest that the relative contributions of these routes of stem cell aging are highly context dependent. In mice, there are fundamental differences in aging wild type strains compared to mutant strains modeling the human situation of an age dependent accumulation of telomere dysfunction. Future studies focusing on model organisms and human aging should attempt to identify molecular mechanisms of stem cell aging relevant to human aging and disease. Such studies should ultimately lead to the identification of possible targets for future therapies aiming to improve regenerative reserve and organ maintenance in response to human aging and disease. 


\section{References:}

Alam, N.A., Gorman, P., Jaeger, E.E., Kelsell, D., Leigh, I.M., Ratnavel, R., Murdoch, M.E., Houlston, R.S., Aaltonen, L.A., Roylance, R.R., et al., 2003. Germline deletions of EXO1 do not cause colorectal tumors and lesions which are null for EXO1 do not have microsatellite instability. Cancer Genet Cytogenet 147, 121-127.

Allsopp, R.C., Morin, G.B., DePinho, R., Harley, C.B., and Weissman, I.L., 2003. Telomerase is required to slow telomere shortening and extend replicative lifespan of HSCs during serial transplantation. Blood 102, 517-520.

Amin, N.S., Nguyen, M.N., Oh, S., and Kolodner, R.D., 2001. exo1-Dependent mutator mutations: model system for studying functional interactions in mismatch repair. Mol cell biol 21, 5142-5155.

Armanios, M.Y., Chen, J.J., Cogan, J.D., Alder, J.K., Ingersoll, R.G., Markin, C., Lawson, W.E., Xie, M., Vulto, I., Phillips, J.A., 3rd, et al.. 2007. Telomerase mutations in families with idiopathic pulmonary fibrosis. N Engl J Med 356, 1317-1326.

Artandi, S.E., Chang, S., Lee, S.L., Alson, S., Gottlieb, G.J., Chin, L., DePinho, R.A., 2000. Telomere dysfunction promotes non-reciprocal translocations and epithelial cancers in mice. Nature 406, 641-5.

Artandi, S.E.,2008. Telomerase as a potential regulator of tissue progenitor cells, In: KL Rudolph (Eds), Telomeres and Telomerase in Agieng, Disease, and cancer, Springer Publishing,pp.203-210.

Aw, D., Silva, A.B., Maddick, M., von Zglinicki, T., Palmer, D.B., 2008. Architectural changes in the thymus of aging mice. Aging Cell 7, 158-67

Bachoo, R.M., Maher, E.A., Ligon, K.L., Sharpless, N.E., Chan, S.S., You, M.J., Tang, Y., DeFrances, J., Stover, E., Weissleder, R., et al., 2002. Epidermal growth factor receptor and Ink4a/Arf: convergent mechanisms governing terminal differentiation and transformation along the neural stem cell to astrocyte axis. Cancer Cell 1, 269-277.

Bagley, J., Cortes, M.L., Breakefield, X.O., Iacomini, J., 2004. Bone marrow transplantation restores immune system function and prevents lymphoma in Atm-deficient mice. Blood 104, 572-8.

Barboza, J.A., Liu, G., Ju, Z., El-Naggar, A.K., and Lozano, G., 2006. p21 delays tumor onset by preservation of chromosomal stability. Proc Natl Acad Sci U S A 103, 19842-19847.

Barlow, C., Hirotsune, S., Paylor, R., Liyanage, M., Eckhaus, M., Collins, F., Shiloh, Y., Crawley, J.N., Ried, T., Tagle, D., Wynshaw-Boris, A., 1996. Atm-deficient mice: a paradigm of ataxia telangiectasia. Cell 86, 159-71.

Barlow, C., Dennery, P.A., Shigenaga, M.K., Smith, M.A., Morrow, J.D., Roberts, L.J., 2nd, Wynshaw-Boris, A., and Levine, R.L., 1999. Loss of the ataxia-telangiectasia gene product causes oxidative damage in target organs. Proc Natl Acad Sci U S A 96, 9915-9919.

Beghe, C., Wilson, A., and Ershler, W.B., 2004. Prevalence and outcomes of anemia in geriatrics: a systematic review of the literature. Am J Med 116 Suppl 7A, 3S-10S.

Bertuch, A.A., and Lundblad, V., 2004. EXO1 contributes to telomere maintenance in both telomerase-proficient and telomerase-deficient Saccharomyces cerevisiae. Genetics 166, 1651-1659.

Bi, X., Wei, S.C., and Rong, Y.S., 2004. Telomere protection without a telomerase; the role of ATM and Mre11 in Drosophila telomere maintenance. Curr Biol 14, 1348-1353.

Blackburn, E.H., 2001. Switching and signaling at the telomere. Cell 106, 661-673.

Bodnar, A.G., Ouellette, M., Frolkis, M., Holt, S.E., Chiu, C.P., Morin, G.B., Harley, C.B., Shay, J.W., Lichtsteiner, S., and Wright, W.E., 1998. Extension of life-span by introduction of telomerase into normal human cells. Science 279, 349-352. 
Boyle, J.M., Mitchell, E.L., Greaves, M.J., Roberts, S.A., Tricker, K., Burt, E., Varley, J.M., Birch, J.M., and Scott, D., 1998. Chromosome instability is a predominant trait of fibroblasts from Li-Fraumeni families. Br J Cancer 77, 2181-2192.

Boyle, M., Wong, C., Rocha, M., and Jones, D.L., 2007. Decline in self-renewal factors contributes to aging of the stem cell niche in the Drosophila testis. Cell Stem Cell 1, 470-478.

Brack, A.S., and Rando, T.A., 2007. Intrinsic changes and extrinsic influences of myogenic stem cell function during aging. Stem Cell Reviews 3, 226-237.

Broccoli, D., Young, J.W., and de Lange, T., 1995. Telomerase activity in normal and malignant hematopoietic cells. Proc Natl Acad Sci U S A 92, 9082-9086.

Brown, J.P., Wei, W., and Sedivy, J.M., 1997. Bypass of senescence after disruption of p21CIP1/WAF1 gene in normal diploid human fibroblasts. Science 277, 831-834.

Callen, E., Jankovic, M., Difilippantonio, S., Daniel, J.A., Chen, H.T., Celeste, A., Pellegrini, M., McBride, K., Wangsa, D., Bredemeyer, A.L., et al., 2007. ATM prevents the persistence and propagation of chromosome breaks in lymphocytes. Cell 130, 63-75.

Castro-Malaspina, H., Harris, R.E., Gajewski, J., Ramsay, N., Collins, R., Dharan, B., King, R., and Deeg, H.J., 2002. Unrelated donor marrow transplantation for myelodysplastic syndromes: outcome analysis in 510 transplants facilitated by the National Marrow Donor Program. Blood 99, 1943-1951.

Cawthon, R.M., Smith, K.R., O'Brien, E., Sivatchenko, A., and Kerber, R.A., 2003. Association between telomere length in blood and mortality in people aged 60 years or older. Lancet 361, 393-395.

Chambers, S.M., Shaw, C.A., Gatza, C., Fisk, C.J., Donehower, L.A., and Goodell, M.A., 2007. Aging hematopoietic stem cells decline in function and exhibit epigenetic dysregulation. PLoS Biology 5, e201.

Ch'ang, H.J., Maj, J.G., Paris, F., Xing, H.R., Zhang, J., Truman, J.P., Cardon-Cardo, C., Haimovitz-Friedman, A., Kolesnick, R., Fuks, Z., 2005. ATM regulates target switching to escalating doses of radiation in the intestines. Nat Med 11, 484-90.

Chang, S., Multani, A.S., Cabrera, N.G., Naylor, M.L., Laud, P., Lombard, D., Pathak, S., Guarente, L., and DePinho, R.A., 2004. Essential role of limiting telomeres in the pathogenesis of Werner syndrome. Nat Genet 36, 877-882.

Cheng, T., Rodrigues, N., Shen, H., Yang, Y., Dombkowski, D., Sykes, M., and Scadden, D.T., 2000. Hematopoietic stem cell quiescence maintained by p21cip1/waf1. Science 287, 1804-1808.

Chin, L., Artandi, S.E., Shen, Q., Tam, A., Lee, S.L., Gottlieb, G.J., Greider, C.W., DePinho, R.A., 1999. p53 deficiency rescues the adverse effects of telomere loss and cooperates with telomere dysfunction to accelerate carcinogenesis. Cell 97, 527-38.

Choudhury, A.R., Ju, Z., Djojosubroto, M.W., Schienke, A., Lechel, A., Schaetzlein, S., Jiang, H., Stepczynska, A., Wang, C., Buer, J., et al., 2007. Cdkn1a deletion improves stem cell function and lifespan of mice with dysfunctional telomeres without accelerating cancer formation. Nat Genet 39, 99-105.

Collerton, J., Martin-Ruiz, C., Kenny, A., Barrass, K., von Zglinicki, T., Kirkwood, T., and Keavney, B., 2007. Telomere length is associated with left ventricular function in the oldest old: the Newcastle 85+ study. Eur Heart J 28, 172-176.

Collins, C.A., Zammit, P.S., Ruiz, A.P., Morgan, J.E., Partridge, T.A., 2007. A population of myogenic stem cells that survives skeletal muscle aging. Stem Cells 25, 885-94.

Conboy, I.M., Conboy, M.J., Wagers, A.J., Girma, E.R., Weissman, I.L., and Rando, T.A., 2005. 
Rejuvenation of aged progenitor cells by exposure to a young systemic environment. Nature 433, 760-764.

d'Adda di Fagagna, F., Reaper, P.M., Clay-Farrace, L., Fiegler, H., Carr, P., Von Zglinicki, T., Saretzki, G., Carter, N.P., and Jackson, S.P., 2003. A DNA damage checkpoint response in telomere-initiated senescence. Nature 426, 194-198.

de Lange, T., 2005. Shelterin: the protein complex that shapes and safeguards human telomeres. Genes Dev 19, 2100-2110.

Donehower, L.A., Harvey, M., Slagle, B.L., McArthur, M.J., Montgomery, C.A., Jr., Butel, J.S., and Bradley, A., 1992. Mice deficient for p53 are developmentally normal but susceptible to spontaneous tumours. Nature 356, 215-221.

Donehower, L.A., Godley, L.A., Aldaz, C.M., Pyle, R., Shi, Y.P., Pinkel, D., Gray, J., Bradley, A., Medina, D., Varmus, H.E., 1995. Deficiency of p53 accelerates mammary tumorigenesis in Wnt-1 transgenic mice and promotes chromosomal instability. Genes Dev 9, 882-95.

Donehower, L.A., 2002. Does p53 affect organismal aging? J Cell Physiol 192, 23-33.

Du, X., Shen, J., Kugan, N., Furth, E.E., Lombard, D.B., Cheung, C., Pak, S., Luo, G., Pignolo, R.J., DePinho, R.A., et al., 2004. Telomere shortening exposes functions for the mouse Werner and Bloom syndrome genes. Mol Cell Biol 24, 8437-8446.

Dumble, M., Moore, L., Chambers, S.M., Geiger, H., Van Zant, G., Goodell, M.A., and Donehower, L.A., 2007. The impact of altered p53 dosage on hematopoietic stem cell dynamics during aging. Blood 109, 1736-1742.

Eilam, R., Peter, Y., Groner, Y., and Segal, M., 2003. Late degeneration of nigro-striatal neurons in ATM-/- mice. Neuroscience 121, 83-98.

Elson, A., Wang, Y., Daugherty, C.J., Morton, C.C., Zhou, F., Campos-Torres, J., and Leder, P., 1996. Pleiotropic defects in ataxia-telangiectasia protein-deficient mice. Proc Natl Acad Sci U S A 93, 13084-13089.

Garcia-Cao, I., Garcia-Cao, M., Tomas-Loba, A., Martin-Caballero, J., Flores, J.M., Klatt, P., Blasco, M.A., and Serrano, M., 2006. Increased p53 activity does not accelerate telomere-driven ageing. EMBO Rep 7, 546-552.

Gire, V., Roux, P., Wynford-Thomas, D., Brondello, J.M., and Dulic, V., 2004. DNA damage checkpoint kinase Chk2 triggers replicative senescence. EMBO J 23, 2554-2563.

Gray, D.H., Seach, N., Ueno, T., Milton, M.K., Liston, A., Lew, A.M., Goodnow, C.C., Boyd, R.L., 2006. Developmental kinetics, turnover, and stimulatory capacity of thymic epithelial cells. Blood $108,3777-85$.

Hackett, J.A., and Greider, C.W., 2003. End resection initiates genomic instability in the absence of telomerase. Mol Cell Biol 23, 8450-8461.

Hao, L.Y., Armanios, M., Strong, M.A., Karim, B., Feldser, D.M., Huso, D., and Greider, C.W., 2005. Short telomeres, even in the presence of telomerase, limit tissue renewal capacity. Cell 123, 1121-1131.

Hayflick, L., 1965. The Limited in Vitro Lifetime of Human Diploid Cell Strains. Exp Cell Res 37, 614-636.

Henckaerts, E., Langer, J.C., and Snoeck, H.W., 2004. Quantitative genetic variation in the hematopoietic stem cell and progenitor cell compartment and in lifespan are closely linked at multiple loci in BXD recombinant inbred mice. Blood 104, 374-379.

Hishiya, A., Ito, M., Aburatani, H., Motoyama, N., Ikeda, K., Watanabe, K., 2005. Ataxia telangiectasia 
mutated (Atm) knockout mice as a model of osteopenia due to impaired bone formation. Bone 37, 497-503.

Hiyama, K., Hirai, Y., Kyoizumi, S., Akiyama, M., Hiyama, E., Piatyszek, M.A., Shay, J.W., Ishioka, S., and Yamakido, M., 1995. Activation of telomerase in human lymphocytes and hematopoietic progenitor cells. J Immunol 155, 3711-3715.

Hong, Y., and Stambrook, P.J., 2004. Restoration of an absent G1 arrest and protection from apoptosis in embryonic stem cells after ionizing radiation. Proc Natl Acad Sci U S A 101, 14443-14448.

Hosen, N., Yamane, T., Muijtjens, M., Pham, K., Clarke, M.F., and Weissman, I.L., 2007. Bmi-1-green fluorescent protein-knock-in mice reveal the dynamic regulation of bmi-1 expression in normal and leukemic hematopoietic cells. Stem Cells 25, 1635-1644.

Ito, K., Hirao, A., Arai, F., Matsuoka, S., Takubo, K., Hamaguchi, I., Nomiyama, K., Hosokawa, K., Sakurada, K., Nakagata, N., et al., 2004. Regulation of oxidative stress by ATM is required for self-renewal of haematopoietic stem cells. Nature 431, 997-1002.

Ito, K., Hirao, A., Arai, F., Takubo, K., Matsuoka, S., Miyamoto, K., Ohmura, M., Naka, K., Hosokawa, K., Ikeda, Y., Suda, T., 2006. Reactive oxygen species act through p38 MAPK to limit the lifespan of hematopoietic stem cells. Nat Med 12, 446-51.

Janzen, V., Forkert, R., Fleming, H.E., Saito, Y., Waring, M.T., Dombkowski, D.M., Cheng, T., DePinho, R.A., Sharpless, N.E., and Scadden, D.T., 2006. Stem-cell ageing modified by the cyclin-dependent kinase inhibitor p16INK4a. Nature 443, 421-426.

Jiang, H., Ju, Z., and Rudolph, K.L., 2007. Telomere shortening and ageing. Z Gerontol Geriatr 40, 314-324.

Jiang H, Schiffer E, Song Z, Wang J, Zürbig P, Thedieck K, Moes S, Bantel H, Saal N, Jantos J, Brecht M, Jenö P, Hall MN, Hager K, Manns MP, Hecker H, Ganser A, Doehner K, Bartke A, Meissner C, Mischak H, Ju Z, Rudolph KL. Proteins induced by telomere dysfunction and DNA damage represent bio-markers of human aging and disease. PNAS 2008, in press

Ju, Z., Jiang, H., Jaworski, M., Rathinam, C., Gompf, A., Klein, C., Trumpp, A., and Rudolph, K.L., 2007. Telomere dysfunction induces environmental alterations limiting hematopoietic stem cell function and engraftment. Nat Med 13, 742-747.

Ju, Z., Choudhury, A.R., Rudolph, K.L., 2007. A dual role of p21 in stem cell aging. Ann N Y Acad Sci 1100, 333-44.

Ju, Z., and Rudolph, L., 2008. Telomere dysfunction and stem cell ageing. Biochimie 90, 24-32.

Kempermann, G., Gast, D., Gage, F.H., 2002. Neuroplasticity in old age: sustained fivefold induction of hippocampal neurogenesis by long-term environmental enrichment. Ann Neurol 52, 135-43.

Kantarjian, H., O'Brien, S., Cortes, J., Giles, F., Faderl, S., Jabbour, E., Garcia-Manero, G., Wierda, W., Pierce, S., Shan, J., Estey, E., 2006b. Results of intensive chemotherapy in 998 patients age 65 years or older with acute myeloid leukemia or high-risk myelodysplastic syndrome: predictive prognostic models for outcome. Cancer 106, 1090-8.

Kempermann, G., Gast, D., Gage, F.H., 2002. Neuroplasticity in old age: sustained fivefold induction of hippocampal neurogenesis by long-term environmental enrichment. Ann Neurol 52, 135-43

Khoo, C.M., Carrasco, D.R., Bosenberg, M.W., Paik, J.H., and Depinho, R.A., 2007. Ink4a/Arf tumor suppressor does not modulate the degenerative conditions or tumor spectrum of the telomerase-deficient mouse. Proc Natl Acad Sci U S A 104, 3931-3936.

Kim, M., Moon, H.B., and Spangrude, G.J., 2003. Major age-related changes of mouse hematopoietic stem/progenitor cells. : Ann N Y Acad Sci 996, 195-208. 
Kippin, T.E., Martens, D.J., and van der Kooy, D. (2005). p21 loss compromises the relative quiescence of forebrain stem cell proliferation leading to exhaustion of their proliferation capacity. Genes Dev 19, 756-767.

Kollman, C., Howe, C.W., Anasetti, C., Antin, J.H., Davies, S.M., Filipovich, A.H., Hegland, J., Kamani, N., Kernan, N.A., King, R., et al., 2001. Donor characteristics as risk factors in recipients after transplantation of bone marrow from unrelated donors: the effect of donor age. Blood 98, 2043-2051.

Krishnamurthy, J., Ramsey, M.R., Ligon, K.L., Torrice, C., Koh, A., Bonner-Weir, S., and Sharpless, N.E., 2006. p16INK4a induces an age-dependent decline in islet regenerative potential. Nature 443, 453-457.

Labrie, J.E., 3rd, Sah, A.P., Allman, D.M., Cancro, M.P., and Gerstein, R.M., 2004. Bone marrow microenvironmental changes underlie reduced RAG-mediated recombination and B cell generation in aged mice. J Exp Med 200, 411-423.

Laird, D.J., von Andrian, U.H., and Wagers, A.J., 2008. Stem cell trafficking in tissue development, growth, and disease. Cell 132, 612-630.

Lee, H.W., Blasco, M.A., Gottlieb, G.J., Horner, J.W., 2nd, Greider, C.W., and DePinho, R.A., 1998. Essential role of mouse telomerase in highly proliferative organs. Nature 392, 569-574.

Levy, M.Z., Allsopp, R.C., Futcher, A.B., Greider, C.W., and Harley, C.B., 1992. Telomere end-replication problem and cell aging. J Mol Biol 225, 951-960.

Liang, Y., Van Zant, G., and Szilvassy, S.J., 2005. Effects of aging on the homing and engraftment of murine hematopoietic stem and progenitor cells. Blood 106, 1479-1487.

Liu, P.K., Kraus, E., Wu, T.A., Strong, L.C., and Tainsky, M.A., 1996. Analysis of genomic instability in Li-Fraumeni fibroblasts with germline p53 mutations. Oncogene 12, 2267-2278.

Lombard, D.B., Beard, C., Johnson, B., Marciniak, R.A., Dausman, J., Bronson, R., Buhlmann, J.E., Lipman, R., Curry, R., Sharpe, A., et al., 2000. Mutations in the WRN gene in mice accelerate mortality in a p53-null background. Mol Cell Biol 20, 3286-3291.

Lynch, H.T., and Lynch, J.F., 2005. What the physician needs to know about Lynch syndrome: an update. Oncology 19, 455-463; discussion 463-454, 466, 469.

Mackall, C.L., Gress, R.E., 1997. Thymic aging and T-cell regeneration. Immunol Rev 160, 91-102. Laird, D.J., von Andrian, U.H., Wagers, A.J., 2008. Stem cell trafficking in tissue development, growth, and disease. Cell 132, 612-30.

Maringele, L., and Lydall, D., 2004. Telomerase- and recombination-independent immortalization of budding yeast. Genes Dev 18, 2663-2675.

Martin, K., Potten, C.S., Roberts, S.A., and Kirkwood, T.B., 1998. Altered stem cell regeneration in irradiated intestinal crypts of senescent mice. J Cell Sci 111 ( Pt 16), 2297-2303.

Matheu, A., Maraver, A., Klatt, P., Flores, I., Garcia-Cao, I., Borras, C., Flores, J.M., Vina, J., Blasco, M.A., Serrano, M., 2007. Delayed ageing through damage protection by the Arf/p53 pathway. Nature 448, 375-9.

Melzer, D., Frayling, T.M., Murray, A., Hurst, A.J., Harries, L.W., Song, H., Khaw, K., Luben, R., Surtees, P.G., Bandinelli, S.S., et al., 2007. A common variant of the p16(INK4a) genetic region is associated with physical function in older people. Mech Ageing Dev 128, 370-377.

Merritt, A.J., Potten, C.S., Kemp, C.J., Hickman, J.A., Balmain, A., Lane, D.P., Hall, P.A., 1994. The role of p53 in spontaneous and radiation-induced apoptosis in the gastrointestinal tract of normal and p53-deficient mice. Cancer Res 54, 614-7. 
Min, H., Montecino-Rodriguez, E., Dorshkind, K., 2004. Reduction in the developmental potential of intrathymic T cell progenitors with age. J Immunol 173, 245-50.

Molofsky, A.V., Slutsky, S.G., Joseph, N.M., He, S., Pardal, R., Krishnamurthy, J., Sharpless, N.E., and Morrison, S.J., 2006. Increasing p16INK4a expression decreases forebrain progenitors and neurogenesis during ageing. Nature 443, 448-452.

Morrison, S.J., Wandycz, A.M., Akashi, K., Globerson, A., and Weissman, I.L., 1996. The aging of hematopoietic stem cells. Nat Med 2, 1011-1016.

Nishimura, E.K., Granter, S.R., and Fisher, D.E., 2005. Mechanisms of hair graying: incomplete melanocyte stem cell maintenance in the niche. Science 307, 720-724.

Pan, L., Chen, S., Weng, C., Call, G., Zhu, D., Tang, H., Zhang, N., and Xie, T., 2007. Stem cell aging is controlled both intrinsically and extrinsically in the Drosophila ovary. Cell Stem Cell 1, 458-469.

Pechnick, R.N., Zonis, S., Wawrowsky, K., Pourmorady, J., and Chesnokova, V., 2008. p21Cip1 restricts neuronal proliferation in the subgranular zone of the dentate gyrus of the hippocampus. Proc Natl Acad Sci U S A 105, 1358-1363.

Peter, Y., Rotman, G., Lotem, J., Elson, A., Shiloh, Y., and Groner, Y., 2001. Elevated Cu/Zn-SOD exacerbates radiation sensitivity and hematopoietic abnormalities of Atm-deficient mice. EMBO J 20, $1538-1546$.

Prowse, K.R., and Greider, C.W., 1995. Developmental and tissue-specific regulation of mouse telomerase and telomere length. Proc Natl Acad Sci U S A 92, 4818-4822.

Qiu, J., Takagi, Y., Harada, J., Rodrigues, N., Moskowitz, M.A., Scadden, D.T., and Cheng, T., 2004. Regenerative response in ischemic brain restricted by p21cip1/waf1. J Exp Med199, 937-945.

Rasheed, N., Wang, X., Niu, Q.T., Yeh, J., and Li, B., 2006. Atm-deficient mice: an osteoporosis model with defective osteoblast differentiation and increased osteoclastogenesis. Hum Mol Genet 15, 1938-1948.

Reese, J.S., Liu, L., and Gerson, S.L., 2003. Repopulating defect of mismatch repair-deficient hematopoietic stem cells. Blood 102, 1626-1633.

Rossi, D.J., Bryder, D., Zahn, J.M., Ahlenius, H., Sonu, R., Wagers, A.J., and Weissman, I.L., 2005. Cell intrinsic alterations underlie hematopoietic stem cell aging. Proc Natl Acad Sci U S A 102, 9194-9199.

Rudolph, K.L., Chang, S., Lee, H.W., Blasco, M., Gottlieb, G.J., Greider, C., and DePinho, R.A., 1999. Longevity, stress response, and cancer in aging telomerase-deficient mice. Cell 96, 701-712.

Ryu, B.Y., Orwig, K.E., Oatley, J.M., Avarbock, M.R., and Brinster, R.L., 2006. Effects of aging and niche microenvironment on spermatogonial stem cell self-renewal. Stem Cells 24, 1505-1511.

Satyanarayana, A., Greenberg, R.A., Schaetzlein, S., Buer, J., Masutomi, K., Hahn, W.C., Zimmermann, S., Martens, U., Manns, M.P., and Rudolph, K.L., 2004. Mitogen stimulation cooperates with telomere shortening to activate DNA damage responses and senescence signaling. Mol Cell Bio 24, 5459-5474.

Saxena, R., Voight, B.F., Lyssenko, V., Burtt, N.P., de Bakker, P.I., Chen, H., Roix, J.J., Kathiresan, S., Hirschhorn, J.N., Daly, M.J., Hughes, T.E., Groop, L., et al., 2007. Genome-wide association analysis identifies loci for type 2 diabetes and triglyceride levels. Science 316, 1331-6.

Schaetzlein, S., Kodandaramireddy, N.R., Ju, Z., Lechel, A., Stepczynska, A., Lilli, D.R., Clark, A.B., Rudolph, C., Kuhnel, F., Wei, K., et al., 2007. Exonuclease-1 deletion impairs DNA damage signaling and prolongs lifespan of telomere-dysfunctional mice. Cell 130, 863-877.

Scott, L.J., Mohlke, K.L., Bonnycastle, L.L., Willer, C.J., Li, Y., Duren, W.L., Erdos, M.R., Stringham, 
H.M., Chines, P.S., Jackson, A.U., Prokunina-Olsson, L., et al., 2007. A genome-wide association study of type 2 diabetes in Finns detects multiple susceptibility variants. Science 316, 1341-5.

Sfeir, A.J., Chai, W., Shay, J.W., and Wright, W.E., 2005. Telomere-end processing the terminal nucleotides of human chromosomes. Mol Cell 18, 131-138.

Sharpless, N.E., Ramsey, M.R., Balasubramanian, P., Castrillon, D.H., and DePinho, R.A., 2004. The differential impact of p16(INK4a) or p19(ARF) deficiency on cell growth and tumorigenesis. Oncogene 23, 379-385.

Shiloh, Y., 2003. ATM and related protein kinases: safeguarding genome integrity. Nat Rev Cancer 3, 155-68.

Siegl-Cachedenier, I., Munoz, P., Flores, J.M., Klatt, P., and Blasco, M.A., 2007. Deficient mismatch repair improves organismal fitness and survival of mice with dysfunctional telomeres. Genes Dev 21 , 2234-2247.

Socie, G., Stone, J.V., Wingard, J.R., Weisdorf, D., Henslee-Downey, P.J., Bredeson, C., Cahn, J.Y., Passweg, J.R., Rowlings, P.A., Schouten, H.C., Kolb, H.J., Klein, J.P., 1999. Long-term survival and late deaths after allogeneic bone marrow transplantation. Late Effects Working Committee of the International Bone Marrow Transplant Registry. N Engl J Med 341, 14-21.

Soussi, T., Wiman, K.G., 2007. Shaping genetic alterations in human cancer: the p53 mutation paradigm. Cancer Cell 12, 303-12.

Sproston, A.R., Boyle, J.M., Heighway, J., Birch, J.M., and Scott, D., 1996. Fibroblasts from Li-Fraumeni patients are resistant to low dose-rate irradiation. Int J Radiat Biol 70, 145-150.

Stepanova, L., and Sorrentino, B.P., 2005. A limited role for p16Ink4a and p19Arf in the loss of hematopoietic stem cells during proliferative stress. Blood 106, 827-832.

Stephan, R.P., Reilly, C.R., and Witte, P.L., 1998. Impaired ability of bone marrow stromal cells to support B-lymphopoiesis with age. Blood 91, 75-88.

Strasser, A., Harris, A.W., Jacks, T., Cory, S., 1994. DNA damage can induce apoptosis in proliferating lymphoid cells via p53-independent mechanisms inhibitable by Bcl-2. Cell 79, 329-39.

Sudo, K., Ema, H., Morita, Y., and Nakauchi, H., 2000. Age-associated characteristics of murine hematopoietic stem cells. J Exp Med 192, 1273-1280.

Sutherland, J.S., Goldberg, G.L., Hammett, M.V., Uldrich, A.P., Berzins, S.P., Heng, T.S., Blazar, B.R., Millar, J.L., Malin, M.A., Chidgey, A.P., Boyd, R.L., 2005. Activation of thymic regeneration in mice and humans following androgen blockade. J Immunol 175, 2741-53

Takai, H., Smogorzewska, A., and de Lange, T., 2003. DNA damage foci at dysfunctional telomeres. Curr Biol 13, 1549-1556.

TeKippe, M., Harrison, D.E., and Chen, J., 2003. Expansion of hematopoietic stem cell phenotype and activity in Trp53-null mice. Exp Hematol 31, 521-527.

Tsakiri, K.D., Cronkhite, J.T., Kuan, P.J., Xing, C., Raghu, G., Weissler, J.C., Rosenblatt, R.L., Shay, J.W., and Garcia, C.K., 2007. Adult-onset pulmonary fibrosis caused by mutations in telomerase. Proc Natl Acad Sci U S A 104, 7552-7557.

Tyner, S.D., Venkatachalam, S., Choi, J., Jones, S., Ghebranious, N., Igelmann, H., Lu, X., Soron, G., Cooper, B., Brayton, C., et al., 2002. p53 mutant mice that display early ageing-associated phenotypes. Nature 415, 45-53.

van Os, R., Kamminga, L.M., Ausema, A., Bystrykh, L.V., Draijer, D.P., van Pelt, K., Dontje, B., and de Haan, G., 2007. A Limited role for p21Cip1/Waf1 in maintaining normal hematopoietic stem cell functioning. Stem Cells 25, 836-843. 
Van Zant, G., Holland, B.P., Eldridge, P.W., and Chen, J.J., 1990. Genotype-restricted growth and aging patterns in hematopoietic stem cell populations of allophenic mice. J Exp Med 171, 1547-1565.

Vaziri, H., Dragowska, W., Allsopp, R.C., Thomas, T.E., Harley, C.B., and Lansdorp, P.M., 1994. Evidence for a mitotic clock in human hematopoietic stem cells: loss of telomeric DNA with age. Proc Natl Acad Sci U S A 91, 9857-9860.

Vulliamy, T., Marrone, A., Szydlo, R., Walne, A., Mason, P.J., and Dokal, I., 2004. Disease anticipation is associated with progressive telomere shortening in families with dyskeratosis congenita due to mutations in TERC. Nat Genet 36, 447-449.

Waterstrat A, Erin Oakley, Alison Miller, Carol Swierski, Ying Liang, and Gary Van Zant. 2008. Mechanisms of Stem cell aging, In: KL Rudolph (Eds), Telomeres and Telomerase in Agieng, Disease, and cancer, Springer Publishing,pp.111-140.

Wei, K., Clark, A.B., Wong, E., Kane, M.F., Mazur, D.J., Parris, T., Kolas, N.K., Russell, R., Hou, H., Jr., Kneitz, B., et al., 2003. Inactivation of Exonuclease 1 in mice results in DNA mismatch repair defects, increased cancer susceptibility, and male and female sterility. Genes Dev 17, 603-614.

Widmann, T., Kneer, H., Konig, J., Herrmann, M., and Pfreundschuh, M., 2008. Sustained telomere erosion due to increased stem cell turnover during triple autologous hematopoietic stem cell transplantation. Exp Hematol36, 104-110.

Wiemann, S.U., Satyanarayana, A., Tsahuridu, M., Tillmann, H.L., Zender, L., Klempnauer, J., Flemming, P., Franco, S., Blasco, M.A., Manns, M.P., et al., 2002. Hepatocyte telomere shortening and senescence are general markers of human liver cirrhosis. FASEB J 16, 935-942.

Wong, K.K., Maser, R.S., Bachoo, R.M., Menon, J., Carrasco, D.R., Gu, Y., Alt, F.W., and DePinho, R.A., 2003. Telomere dysfunction and Atm deficiency compromises organ homeostasis and accelerates ageing. Nature 421, 643-648.

Wright, W.E., Piatyszek, M.A., Rainey, W.E., Byrd, W., and Shay, J.W., 1996. Telomerase activity in human germline and embryonic tissues and cells. Dev Genet 18, 173-179.

Wright, W.E., and Shay, J.W., 1992. The two-stage mechanism controlling cellular senescence and immortalization. Exp Gerontol 27, 383-389.

Wu, Y., Berends, M.J., Post, J.G., Mensink, R.G., Verlind, E., Van Der Sluis, T., Kempinga, C., Sijmons, R.H., van der Zee, A.G., Hollema, H., et al., 2001. Germline mutations of EXO1 gene in patients with hereditary nonpolyposis colorectal cancer (HNPCC) and atypical HNPCC forms. Gastroenterology 120, 1580-1587.

Xu, Y., Ashley, T., Brainerd, E.E., Bronson, R.T., Meyn, M.S., and Baltimore, D., 1996. Targeted disruption of ATM leads to growth retardation, chromosomal fragmentation during meiosis, immune defects, and thymic lymphoma. Genes Dev 10, 2411-2422.

Yang, L., Wang, L., Geiger, H., Cancelas, J.A., Mo, J., Zheng, Y., 2007. Rho GTPase Cdc42 coordinates hematopoietic stem cell quiescence and niche interaction in the bone marrow. Proc Natl Acad Sci U S A 104, 5091-6.

Yakoub-Agha, I., Mesnil, F., Kuentz, M., Boiron, J.M., Ifrah, N., Milpied, N., Chehata, S., Esperou, H., Vernant, J.P., Michallet, M., Buzyn, A., Gratecos, N., Cahn, J.Y., Bourhis, J.H., Chir, Z., Raffoux, C., Socie, G., Golmard, J.L., Jouet, J.P., 2006. Allogeneic marrow stem-cell transplantation from human leukocyte antigen-identical siblings versus human leukocyte antigen-allelic-matched unrelated donors (10/10) in patients with standard-risk hematologic malignancy: a prospective study from the French Society of Bone Marrow Transplantation and Cell Therapy. J Clin Oncol 24, 5695-702.

Zediak, V.P., Maillard, I., Bhandoola, A., 2007. Multiple prethymic defects underlie age-related loss of 


\section{ACCEPTED MANUSCRIPT}

T progenitor competence. Blood 110, 1161-7.

Zeggini, E., Weedon, M.N., Lindgren, C.M., Frayling, T.M., Elliott, K.S., Lango, H., Timpson, N.J., Perry, J.R., Rayner, N.W., Freathy, R.M., Barrett, J.C., et al., 2007. Replication of genome-wide association signals in UK samples reveals risk loci for type 2 diabetes. Science 316, 1336-41

Zhao, R., Xuan, Y., Li, X., and Xi, R., 2008. Age-related changes of germline stem cell activity, niche signaling activity and egg production in Drosophila. Aging Cell 7, 344-354.

Zimmermann, S., and Martens, U.M., 2005. Telomere dynamics in hematopoietic stem cells. Curr Mol Med 5, 179-185.

Zou, Y., Sfeir, A., Gryaznov, S.M., Shay, J.W., and Wright, W.E., 2004. Does a sentinel or a subset of short telomeres determine replicative senescence? Mol Biol Cell 15, 3709-3718. 
Table 1

Aging of hematopoietic stem cell is influenced by cell intrinsic and cell extrinsic mechanisms. In mice, telomere dysfunction changes the relative contribution of cell extrinsic and intrinsic mechanisms to HSC aging (Table 1).

\begin{tabular}{|c|c|c|c|}
\hline Stem & Humans & Wildtype mice & Telomere dysfunctional mice \\
\hline $\begin{array}{l}\text { HSC self } \\
\text { renewal }\end{array}$ & $\begin{array}{l}\text { Decreased CD34+ HSCs with } \\
\text { human aging (Waterstrat, et.al., } \\
\text { 2008.). The contribution of cell } \\
\text { intrinsic or extrinsic } \\
\text { mechanisms is unknown. }\end{array}$ & $\begin{array}{l}\text { An increase in absolute } \\
\text { number of HSC in the } \\
\text { C57B1/6J strain but a } \\
\text { decrease in the DBA and } \\
\text { Balb/C strain. (Morrison et } \\
\text { al., 1996; Sudo et al., } \\
\text { 2000; Rossi et al., 2005; } \\
\text { Waterstrat et al., 2008). } \\
\text { Cell intrinsic: genetic } \\
\text { factors modify HSC self } \\
\text { renewal (Yang et al. 2007). } \\
\text { The contribution of Cell } \\
\text { extrinsic mechanisms is } \\
\text { unknown }\end{array}$ & $\begin{array}{l}\text { Reduced number in aged telomere } \\
\text { dysfunction mice compared to } \\
\text { age-matched wildtype control mice. } \\
\text { (Choudhury et al. 2007, Ju et al., } \\
\text { 2007) } \\
\text { Cell intrinsic: Reduced self } \\
\text { renewal of transplanted HSCs with } \\
\text { dysdfucntional telomeres (Ju et al., } \\
\text { 2007, Rossi et al., 2007) } \\
\text { Cell extrinsic: Telomere } \\
\text { dysfunction impairs the capacity of } \\
\text { stromal cells to maintain functional } \\
\text { HSCs (Ju et al., 2007) }\end{array}$ \\
\hline $\begin{array}{l}\text { Repopulation } \\
\text { capacity }\end{array}$ & $\begin{array}{l}\text { Cell intrinsic: Telomere } \\
\text { shortening and declined } \\
\text { repopulating capacity with } \\
\text { increasing donor age (Widmann } \\
\text { et al.,2008; Castro-Malaspina et } \\
\text { al., 2002; Kollman et al., 2001 } \\
\text { Yakoub-Agha et al.,2006). } \\
\text { Cell extrinsic: Long-term } \\
\text { survival of bone marrow } \\
\text { transpanted patients is } \\
\text { significantly reduced in older } \\
\text { recipients. (Socie et al., 1999) } \\
\text { ( Kantarjian et al., 2006) }\end{array}$ & $\begin{array}{l}\text { Cell intrinsic: Decline in } \\
\text { repopulating capacity on a } \\
\text { per cell basis during aging } \\
\text { (Chambers et al., 2007). } \\
\text { Cell extrinsic: Diminished } \\
\text { homing and engraftement } \\
\text { of transplanted cells } \\
\text { depending on recipient age } \\
\text { (Laird et al., 2008; Liang } \\
\text { et al., 2005) }\end{array}$ & $\begin{array}{l}\text { Cell intrinsic: DNA damage } \\
\text { checkpoints induced by telomere } \\
\text { dysfunction diminished the number } \\
\text { and self-renewal capacity of } \\
\text { LT-HSC (Choudhury et al., 2007; } \\
\text { Allsopp et al., 2003) } \\
\text { Cell extrinsic: Telomere shortening } \\
\text { of the donor impairs engraftment of } \\
\text { transplanted wildtype HSCs (Ju et } \\
\text { al., 2007) }\end{array}$ \\
\hline $\begin{array}{l}\text { Skewing of } \\
\text { hematopoiesis }\end{array}$ & $\begin{array}{l}\text { Loss of immune function and } \\
\text { increased incidence of myeloid } \\
\text { proliferative disorders including } \\
\text { acute myeloid leukemia, } \\
\text { indicating a skewed } \\
\text { hematopoiesis with age. The } \\
\text { contribution of cell intrinsic or } \\
\text { extrinsic mechanisms are } \\
\text { unknown. }\end{array}$ & $\begin{array}{l}\text { Impaired Lymphopoiesis } \\
\text { and increase myelopoiesis } \\
\text { in aging mice. } \\
\text { Cell intrinsic: Gene } \\
\text { expression changes in } \\
\text { aging HSCs favor } \\
\text { myelopoiesis and impair } \\
\text { lymphopoiesis (Chambers } \\
\text { et al., 2007; Rossi et al., } \\
\text { 2005) }\end{array}$ & $\begin{array}{l}\text { Telomere dysfunction accelerates } \\
\text { skewing of hematopoiesis in } \text { Terc }^{-/-} \\
\text {mice compared to wildtype mice } \\
\text { Cell intrinsic: no evidence for } \\
\text { contribution of cell intrinsic } \\
\text { mechanisms. } \\
\text { Skewing is completely measured } \\
\text { after transplantation of Terc }{ }^{-/} \text {HSCs } \\
\text { into wildtype recipient mice. (Ju et } \\
\text { al.,2007) }\end{array}$ \\
\hline
\end{tabular}




\begin{tabular}{|c|c|c|c|}
\hline $\begin{array}{l}\text { Thymus } \\
\text { involution }\end{array}$ & $\begin{array}{l}\text { Reduced thymus output and } \\
\text { altered structure of the aging } \\
\text { thymus (for review see } \\
\text { Sutherland et al.) } \\
\text { The contribution of cell intrinsic } \\
\text { mechanisms is unknown. . } \\
\text { Cell extrinsic: Rescue of thymus } \\
\text { involution by androgen depletion } \\
\text { (Sutherland et al., 2005) }\end{array}$ & 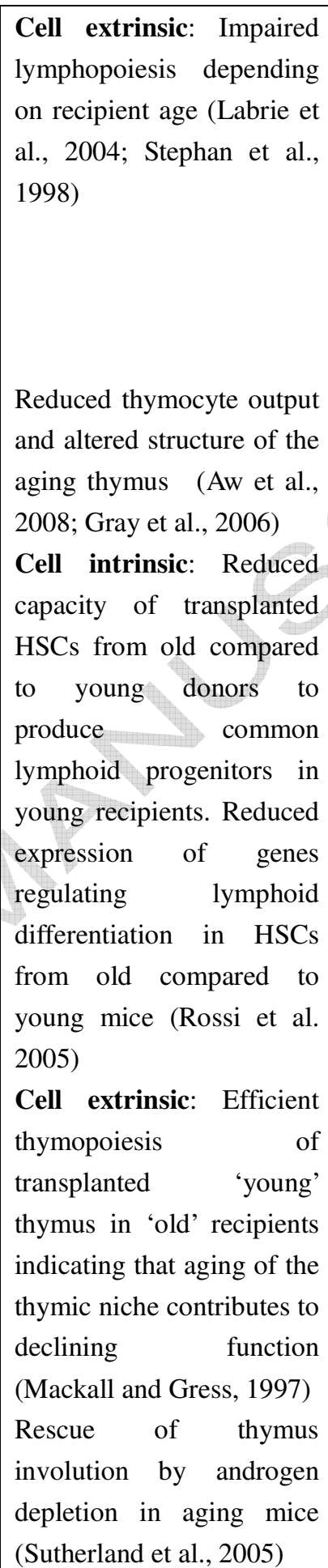 & $\begin{array}{l}\text { Cell extrinsic: Appears to be } \\
\text { dominant mechanisms, HSCs of } \\
\text { young wildtype show skewing after } \\
\text { transplantation into old Terc }{ }^{--} \text {mice } \\
\text { with dysfunctional telomere, but } \\
\text { not after transplantation in age } \\
\text { matched wildtype mice.(Ju et } \\
\text { al.,2007) } \\
\text { Premature involution of the thymus } \\
\text { The contribution of cell intrinsic } \\
\text { or extrinsic mechanisms are } \\
\text { largely unknown. }\end{array}$ \\
\hline
\end{tabular}


Table 2 Consequences of DNA damage checkpoint mutations in humans, wildtype mice, and telomere dysfunctional mice

\begin{tabular}{|c|c|c|c|}
\hline Gene & $\begin{array}{l}\text { Deletion/Mutation in } \\
\text { Human } \\
\text { Diseases/Cancer }\end{array}$ & Deletion in Wildtype mice & $\begin{array}{l}\text { Deletion in telomere } \\
\text { dysfunctional mice }\end{array}$ \\
\hline Atm & $\begin{array}{l}\text { Neurodegeneration, } \\
\text { ataxia.(Shiloh,2003) } \\
\text { Chromosomal } \\
\text { instability.(Shiloh, } \\
\text { 2003) } \\
\text { Radiosensitivity. } \\
\text { (Shiloh,2003) } \\
\text { Immunodeficiency. } \\
\text { (Shiloh, 2003) }\end{array}$ & $\begin{array}{l}\text { Shortened lifespan due to cancer formation } \\
\text { (Elson et al.,1996; Barlow et al.,1996) } \\
\text { Impaired repopulation capacity of HSCs due } \\
\text { to increased reactive oxygen species. (Ito et } \\
\text { al., 2004) } \\
\text { Modest neurodegeneration, no functional } \\
\text { defect (Eilam et al., 2003). } \\
\text { Low level of chromosomal instability } \\
\text { (Callen et al., 2007). } \\
\text { Radiosensitivity. (Barlow et al.,1996;Ch'ang } \\
\text { et al., 2005; Peter et al., 2001) } \\
\text { Immunodeficieny. (Elson et al.,2001;Xu et } \\
\text { al., 1996; Bagley et al., 2004) } \\
\text { Osteoporosis. (Rasheed et al., 2006; Hishiya } \\
\text { et al.,2005) }\end{array}$ & $\begin{array}{l}\text { Shortened lifespan due to } \\
\text { premature aging. (Wong et } \\
\text { al., 2003) } \\
\text { Impaired colony formation } \\
\text { of hematopoietic cells, } \\
\text { (Wong et al., 2003) } \\
\text { impaired proliferation of } \\
\text { neuronal stem cells. (Wong } \\
\text { et al., 2003) } \\
\text { Increased } \\
\text { neurodegeneration, } \\
\text { hypokinesia. } \\
\text { High level of chromosomal } \\
\text { instability. (Wong et al., } \\
\text { 2003) } \\
\text { Not investigated. } \\
\text { Not investigated. } \\
\text { Not investigated. }\end{array}$ \\
\hline p53 & $\begin{array}{l}\text { Shortened lifespan due } \\
\text { to cancer formation } \\
\text { (Li } \quad \text { Fraumeni } \\
\text { Syndrome) (Soussi et } \\
\text { al.,2007) } \\
\\
\text { Radioresistence } \\
\text { (Sproston et al., 1996) } \\
\text { Chromosomal } \\
\text { instability. }\end{array}$ & $\begin{array}{l}\text { Shortened lifespan due to cancer formation } \\
\text { (Donehower et al.,1992) } \\
\text { Increased self renewal, increased repopulation } \\
\text { capacity, but impaired long term function of } \\
\text { HSCs (Strasser et al.,1994; Dumble et al., } \\
\text { 2007; TeKippe et al., 2003) } \\
\text { Radioresistence. (Merritt et al., 1994) } \\
\text { Chromosomal instability. (Donehower et } \\
\text { al.,1995) }\end{array}$ & $\begin{array}{l}\text { Shortened lifespan due to } \\
\text { cancer formation. (Artandi } \\
\text { et al 2000) } \\
\text { Rescue of apoptosis in } \\
\text { germ cells and intestinal } \\
\text { stem-/progentior cells, HSC } \\
\text { function not analyzed.(Chin } \\
\text { et al.,1999) } \\
\text { Not investigated. } \\
\text { Increased chromosomal } \\
\text { instability(Artandi et al }\end{array}$ \\
\hline
\end{tabular}




\begin{tabular}{|c|c|c|c|}
\hline & & $\begin{array}{l}\text { Extra copy of naturally regulated p53: delayed } \\
\text { aging (Matheu et al., 2007) } \\
\text { Overactive mutant p53: premature aging, } \\
\text { impaired self renewal and function of } \\
\text { HSCs(Tyner et al.,2002; Donehower, 2002) }\end{array}$ & $\begin{array}{l}2000) \\
\text { Extra copy of naturally } \\
\text { regulated p53: no rescue of } \\
\text { premature } \\
\text { (Garcia-Cao et al., 2006) }\end{array}$ \\
\hline p21 & $\begin{array}{l}\text { Mutations are not } \\
\text { associated with human } \\
\text { diseases or cancer }\end{array}$ & $\begin{array}{l}\text { Increased cycling of HSCs (under debate), } \\
\text { Exhaustion of HSCs when exposed to } \\
\text { chemotherapy and replicative stress.(Cheng et } \\
\text { al., 2000) but under steady state the role of } \\
\text { p21 n HSCsfuncton epends on strain } \\
\text { background. (van Os et al., 2007) } \\
\text { Increased neurogenesis and neuronal } \\
\text { regeneration, exhaustion of neuronal stem } \\
\text { cells during aging.(Pechnick et al., 2008; } \\
\text { Kippin et al., 2005; Qiu et al., 2004) }\end{array}$ & $\begin{array}{l}\text { Elongated lifespan. } \\
\text { (Choudhury et al., 2007) } \\
\text { Improved maintenance and } \\
\text { function of HSCs. } \\
\text { (Choudhury et al., 2007) } \\
\text { Improved maintenance of } \\
\text { intestinal stem and } \\
\text { progenitor cells. } \\
\text { (Choudhury et al., 2007) } \\
\text { No rescue of apoptosis in } \\
\text { intestinal progenitor cells } \\
\text { and germ cells. (Choudhury } \\
\text { et al., 2007) }\end{array}$ \\
\hline p16/p19 & $\begin{array}{l}\text { Polymorphisms are } \\
\text { associated with aging } \\
\text { (Saxena et al., 2007; } \\
\text { Scott et al., 2007; } \\
\text { Zeggini et al., 2007; } \\
\text { Melzer et al., 2007;) }\end{array}$ & $\begin{array}{l}\text { P16-deletion: improved regenerative capacity } \\
\text { in different stem cell compartments: HSCs, } \\
\text { neuronal stem cells, pancreatic islets. } \\
\text { (Molofsky et al., 2006; Krishnamurthy et al., } \\
\text { 2006;Janzen et al., 2006; Stepanova and } \\
\text { Sorrentino, 2005) }\end{array}$ & $\begin{array}{l}\text { No improvement in organ } \\
\text { maintenance and lifespan in } \\
\text { p16Ink4A, P19ARF } \\
\text { compound mutant mice } \\
\text { (Khoo et al., 2007) }\end{array}$ \\
\hline $\begin{array}{l}\text { DNA-Mi } \\
\text { smatch } \\
\text { Repair } \\
\text { genes: } \\
\text { Exo-1 } \\
\\
\text { MSH2 }\end{array}$ & $\begin{array}{l}\text { Herditary non } \\
\text { polyposis coli (under } \\
\text { debate) ( Wu et al., } \\
2001 \text { ) } \\
\text { skin leiomyomata } \\
\text { no evidence for } \\
\text { mismatch repair defect } \\
\text { Lynch syndrome: } \\
\text { hereditary nonpolyposis } \\
\text { colorectal cancer (Lynch } \\
\text { and Lynch, 2005); } \\
\text { Mismatch repair defect } \\
\text { Colorectal cancer, } \\
\text { extra-CRC cancers. } \\
\end{array}$ & $\begin{array}{l}\text { Shortened lifespan due to lymphoma at early } \\
\text { age.(De wind et al.,1995) } \\
\text { Reduced repopulation capacity of HSCs. } \\
\text { (Reese et al., 2003) }\end{array}$ & $\begin{array}{l}\text { Increased lifespan } \\
\text { (Schaetzlein et al., 2007). } \\
\text { Improved maintenance of } \\
\text { intestinal stem cells } \\
\text { (Schaetzlein et al., 2007) } \\
\text { Rescue in skewing of } \\
\text { hemato-lymphopiesis } \\
\text { Impaired DNA damage } \\
\text { signaling. (Schaetzlein et } \\
\text { al., 2007) }\end{array}$ \\
\hline
\end{tabular}

